\title{
COVID-19 evidence for all: development of a learning object in health teaching
}

\author{
COVID-19 evidências para todos: desenvolvimento de um \\ objeto de aprendizagem no ensino em saúde \\ COVID-19 evidencias para todos: desarrollo de un objeto \\ de aprendizaje en la enseñanza en salud
}

\section{Lindayane Debom Motta ${ }^{a}$ \\ Aline Angeli de Freitas ${ }^{\mathrm{a}}$ \\ Ronei Xavier Janovik Júnior ${ }^{a}$ \\ Carine Raquel Blatt ${ }^{a}$ \\ Rita Catarina Aquino Caregnato ${ }^{\mathrm{a}}$}

How to cite this article:

Motta LD, Freitas AA, Janovik Júnior RX, Blatt CR, Caregnato RCA. COVID-19 evidence for all: development of a learning object in health teaching. Rev Gaúcha Enferm. 2021;42(spe):e20200281 doi: https://doi.org/10.1590/19831447.2021.20200281
- Universidade Federal de Ciências da Saúde de Porto Alegre (UFCSPA), Programa de Pós Graduação Profissional em Enfermagem. Porto Alegre, Rio Grande do Sul, Brasil.

\section{ABSTRACT}

Objective: Describe the development of a learning object focused on scientific evidence about COVID-19.

Method: Experience report on the production of a learning object based on the DADI web sites methodology, aimed at adults and children, built by nurses and academics from a Brazilian Federal University in 2020. Data collection in databases and reference organizations. Monitored performance through Google Analytics.

Results: Website created, "COVID-19 Evidence for All", with intuitive design and didactic language aimed at three audiences: health professionals, adult population, and children. In the first month after implementation, the website was accessed by 3,313 users, proving to be an efficient strategy for disseminating knowledge.

Conclusion: The development of the website involved professors, academics and master's students in the production of educational material aimed at prevention, promotion and maintenance of health. The resource allows quick consultation of the best scientific evidence available to date.

Keywords: Coronavirus infections. Pandemics. Computer communication networks. Health education. Evidence-based practice. Empowerment for health.

\section{RESUMO}

Objetivo: Descrever o desenvolvimento de um objeto de aprendizagem focado em evidências científicas sobre COVID-19.

Método: Relato de experiência sobre produção de um objeto de aprendizagem fundamentado na metodologia web sites DADI, direcionado ao público adulto e infantil, construído por enfermeiras e acadêmicos de uma Universidade Federal brasileira, em 2020. Coleta de dados em bases de dados e organizações de referências. Monitorado desempenho através do Google Analytics.

Resultados: Elaborado site "COVID-19 evidências para todos", com design intuitivo e linguagem didática direcionado a três públicos: profissionais de saúde, população adulta e crianças. No primeiro mês após implementação, o site foi acessado por 3.313 usuários, mostrando ser uma estratégia eficiente para disseminação de conhecimento.

Conclusão: 0 desenvolvimento do site envolveu docentes, acadêmicos e mestrandos de Enfermagem na confecção de material educativo direcionado à prevenção, promoção e manutenção da saúde. 0 recurso permite consulta rápida às melhores evidências científicas disponíveis até o momento.

Palavras-chave: Infecções por coronavírus. Pandemias. Redes de comunicação de computadores. Educação em saúde. Prática clínica baseada em evidências. Empoderamento para a saúde.

\section{RESUMEN}

Objetivo: Describe el desarrollo de un objeto de aprendizaje centrado en la evidencia científica sobre COVID-19.

Método: Informe de experiencia sobre la producción de un objeto de aprendizaje basado en la metodología de los sitios web DADI, dirigido a adultos y niños, construido por enfermeras y académicos de una Universidad Federal de Brasil, en 2020. Recopilación de datos en bases de datos y organizaciones de referencia. Rendimiento supervisado a través de Google Analytics.

Resultados: Sitio web creado, "Evidencia COVID-19 para todos", con diseño intuitivo y lenguaje didáctico dirigido a tres audiencias: profesionales de la salud, población adulta y niños. En el primer mes después de la implementación, el sitio fue accedido por 3.313 usuarios, demostrando ser una estrategia eficiente para diseminar conocimiento.

Conclusión: El desarrollo del sitio involucró a profesores, académicos y estudiantes de maestría en enfermería en la preparación de material educativo dirigido a la prevención, promoción y mantenimiento de la salud. El recurso permite una consulta rápida a las mejores recomendaciones científicas.

Palabras clave: Infecciones por coronavirus. Pandemias. Redes de comunicación de computadores. Educación en salud. Practica clinica basada en la evidencia. Empoderamiento para la salud. 


\section{INTRODUCTION}

In December 2019, Chinese authorities reported to the World Health Organization (WHO) cases of viral pneumonia of unknown cause in the city of Wuhan ${ }^{(1)}$. The surveillance routine allowed the analysis of these patients to reveal a new type of coronavirus(1), initially named 2019-nCoV and later replaced by SARS-CoV-2, which causes the respiratory disease called COVID-19(2). This virus spread rapidly ${ }^{(3)}$, with the first case confirmed in Brazil on February 26, 2020, in São Paulo(4). On March 11, 2020, a pandemic was announced by $\mathrm{WHO}^{(3,5)}$.

It has not yet been identified a direct-acting antiviral agent for SARS-CoV-2, and vaccines are still in development ${ }^{(5)}$. Therefore, to break the chain of transmission, it is essential to adopt effective measures for the prevention and infection contro|(5).

The education of health professionals and the population about COVID-19 is of great relevance, especially at a time when, in addition to controlling the spread of the virus, it is necessary to control the information and disseminated fake news ${ }^{(6-7)}$. Educational health measures are methods used to inform and influence individual and collective decisions, therefore, essential to promote infection prevention measures ${ }^{(7)}$.

Learning objects $(\mathrm{LO})$ are resources to support teaching that can be used during learning supported by technologies ${ }^{(8)}$. The use of LO by electronic means has become an important tool for health education ${ }^{(8)}$.

The Nursing Now campaign in Brazil aims to "invest in strengthening education" and "disseminate effective and innovative Nursing practices based on scientific evidence, at national and regional levels"(9). In this context, the guiding question emerged: how to build a LO with scientific evidence about COVID-19 to educate various audiences? This article aims to describe the development of a LO focused on scientific evidence about COVID-19.

\section{METHOD}

Experience report about the construction of a digital LO with scientific evidence about COVID-19, built at a Federal University in the south of Brazil by a master's student nurse, professors and academics of Nursing, with participants from the existing Nursing group at the institution. The LO was aimed at the adult population (lay people and health professionals) and children over six years.

The production followed the website development methodology called DADI, with four stages: 1. Definition: elaboration of the first information about the scope and depth of the process; 2 . Architecture: evaluation of the structuring and content, carrying out visual planning; 3. Design: creation of the LO with the definition of the graphic-visual presentation; and 4. Implementation: the functions are tested and evaluated ${ }^{(10)}$. The steps will be detailed in the results.

For its creation, the Google Sites tool was chosen, a resource that provides layout and addresses for free websites on the web. The images used are free licensed on the internet. The chosen method of monitoring performance was Google Analytics, a free tool that allows measuring the number of users and access to the website. The performance evaluation period was between April 30, 2020 and May 30, 2020. As it is an educational material, no sample size calculation was performed.

\section{RESULTS}

\section{Development of the learning object}

In the "definition" stage, virtual meetings were held with nursing professors from different areas and nursing students. In the "architecture", it was projected the subject's selection on the website and how it would be transmitted to the target audiences. In "design", short texts were created with accessible language for each audience, based on scientific evidence. Content presented in question-and-answer format, with the reference in hyperlink.

In April 2020, the "implementation" was carried out, testing, and evaluating the functions of the website and after promoting it to the public. As this is a product resulting from a Professional Master's Program in Nursing, its first dissemination occurred on the Program's social network page, on April 30, 2020, and afterwards on public and private social networks.

The website was entitled "COVID-19: evidence for all", with the intention of announcing that it is aimed at all audiences. The language used was Portuguese from Brazil. Access is via the address: https://sites.google.com/view/ coronavirus-ufcspa.

\section{Presentation of the website "COVID-19: evidence for all"}

The home page was designed in an intuitive way, allowing the user to easily find information, containing three icons named: health professionals; general population; and children. The user clicks on the icon according to his/her profile.

The space called "Science Explains" is subdivided into three parts: 1) it provides tips for identifying fake news and/or without scientific evidence; 2) provides synthesized and translated scientific articles for the population's understanding; 
and 3) it presents a list of reliable sites, separated by language, with access to scientific videos and hyperlinks to free courses for health professionals. In another space there is an area called "current situation", in which are identified the updated numbers of COVID-19 cases and confirmed deaths. For worldwide information, the Johns Hopkins University page was added, which presents a dashboard with updated numbers. Below, hyperlinks are available directing the user to pages with data from Brazil.

For children, an area was created where materials for printing, online games and playful stories are available to learn while playing. Regarding the specific content presented for each target audience, Chart 1 presents a summary of the topics addressed.

For the inclusion of materials produced by third parties, or other higher education institutions, the researchers assessed the quality and source of the information, requesting authorization from the authors via email or message on social networks. Nursing students collaborated with content ideas, downloadable infographics, and development of educational history for children. Academics from the "Nursing Now" group prepared a booklet with frequently asked questions that arise among health professionals and answers with technical evidence information.

Regarding the rapid dynamics of information changes, an alert to the user was placed at the top of the pages saying:
"Attention, be aware that this is a situation in rapid evolution. The information will be updated and changed as appropriate, therefore, check the latest version".

\section{Monitoring the performance of the learning object}

In the first month, the website was accessed by 3,313 users, that is, the number of devices that accessed the LO at least once. During that period, there were 12,634 page views. Regarding accesses, it was found that 50 accesses were not performed in Brazil, being: 18 from the United States, nine from Argentina, five from Portugal, two from Canada, England, and Ireland and one from Belgium and Chile.

Through the use of intelligent systems, the profile of $49 \%$ of users was identified in Google Analytics. Form the 3,125 users, the gender of 1,644 was identified, being $69.16 \%$ female $(n=1,137)$ and $30.84 \%$ male $(n=507)$. The age group was able to identify 1,569 users, being 68\% ( $n=1073)$ between 18 and 44 years old and $32 \%(n=496)$ over 45 years old.

A responsive website has been developed, that is, the website automatically fits into the user's device. In the analysis of the most used devices for access, $91 \%(n=2,848)$ were used by cell phones, $8.8 \%(n=274)$ by desktops and $0.16 \%$ $(\mathrm{n}=5)$ by tablets.

\footnotetext{
Target audience Topics addressed

\begin{tabular}{|c|l|}
\hline Children & $\begin{array}{l}\text { Uncomplicated hand hygiene for children, "Print to play," "Play to learn” and "Read } \\
\text { to understand" }\end{array}$ \\
\hline General population & $\begin{array}{l}\text { Risk population, Hand hygiene, Masks, Disposable gloves, Virus survival, Distancing, isolation } \\
\text { and quarantine, Home care, Supermarket, Work, Transportation, Pets, Children, Sexual } \\
\text { relations, Maternity, Elderly, Exercises at Home, Vaccine, Treatment, when looking for a hospital, } \\
\text { Educational videos }\end{array}$ \\
\hline Health professional & $\begin{array}{l}\text { Common information: Hand hygiene, Personal protective equipment, Virus survival, Hygiene, } \\
\text { materials and waste, Aerosols, Vaccine, Diagnosis, Treatment, Hospital discharge, Death, Mental } \\
\text { health, Downloadable materials, Questions and answers, Educational videos. } \\
\text { Specific information by area: Care simulation, Obstetrics, Surgical Center, Materials and } \\
\text { sterilization center, Nursing Diagnostics, Geriatrics, Pediatrics, Diagnostic imaging, among } \\
\text { others under construction }\end{array}$ \\
\hline
\end{tabular}
}

Chart 1 - Distribution of topics addressed according to the target audience on the website "COVID-19: evidence for all", Porto Alegre, 2020

Source: Authors, 2020. Available at: https://sites.google.com/view/coronavirus-ufcspa 


\section{DISCUSSION}

It is known that many people use the internet to learn about diagnoses, review possible treatments, evaluate medications and find other types of health information, both for themselves and for the family ${ }^{(11)}$. Thus, it was decided to use information technology to promote teaching in the area of Infection Control and Prevention.

Currently, the world, in addition to facing the pandemic, suffers an information epidemic called "infodemia", referring to a large increase in the volume of information, which rapidly multiplies exponentially ${ }^{(6)}$. As for the pandemic, it appears that some information are accurate and some are not, making it difficult for reputable sources and reliable guidance to be found and prioritized by people in general, including health professionals, making this false or inaccurate information affect processes of making important decisions ${ }^{(6)}$. For this reason, for the construction of the "COVID-19 evidence for all" website, used only sources from trusted organizations, to avoid the spread of wrong information.

Media and social networks are powerful marketing strategy tools, as $80 \%$ of Brazilian Internet users use any of these tools ${ }^{(12)}$. For this reason, this strategy was adopted for the website dissemination. Regarding page views, a significant number was identified in the first week, between April 30 and May 7, with an average of 1,285 views per day. It is believed that this amount is related to the intense dissemination of the website in the first days, being shared by several people in media, social networks and in groups of instant messages. After that time, views stabilized at an average of 98 views per day.

It was noted that 50 users were not from Brazil, since the official disclosures occurred only in the country. It is believed that Brazilians living outside the country had access through social networks of friends and/or family. For this reason, more and more health professionals use social networks, as they allow overcoming time and space limitations, allowing reaching a greater number of people ${ }^{(13)}$.

Studies have shown that the male population tends to manifest COVID-19 more seriously than the female ${ }^{(14)}$. It can be associated that men have higher risk behavior and less demand for health care ${ }^{(14)}$. The data found about the gender of users who accessed the website reinforces this idea, as $69 \%$ of users were women seeking information.
According to data from 2019, released by the Internet Steering Committee in Brazil (Comitê Gestor da Internet no Brasil - CGI.br), the country has 134 million internet users, which means that for every four Brazilians, three have access to the internet ${ }^{(15)}$. The cell phone is the main device used to access the internet, used by $99 \%$ of network users, of which $58 \%$ access the internet exclusively by mobile phone ${ }^{(15)}$. This data justifies that $91 \%$ of the accesses to the website were made through cell phones (mobile platform), reinforcing the increasingly important role of cell phones in accessing informative content. This result corroborates the purpose for which the website was built, thinking of being a source of quick consultation, to be used anywhere when doubts arise.

The limitation found in the implementation of this learning object was the time for construction, since it occurred in the middle of the pandemic. In addition, the means of dissemination were limited, as we use many personal social media profiles.

\section{FINAL CONSIDERATIONS}

The development of a learning object with scientific evidence about COVID-19, during the pandemic, meets one of the goals of the Nursing Now campaign, to invest in education by disseminating scientific evidence for application in practice.

The creation of the website was made possible by the teamwork, with active participation in the selection and preparation of educational material. The intuitive design of the website, with a didactic language and easy to understand, allows quick consultation, with access to the best recommendations for prevention, promotion, and maintenance of health, allowing clarifications about COVID-19 to health professionals, adult population and children.

It is considered as limitations the short time to evaluate the learning object and the profile of users raised. It is believed to exist bias, since many devices are shared by more than one user and children use devices from older users.

Developing educational actions in health promotion, risk prevention, reduction of diseases and illnesses, considering the specificity of different social groups and different life processes is one more of the attributions of Nursing. 


\section{REFERENCES}

1. Li Q, Guan X, Wu P, Wang X, Zhou L, Tong Y, et al. Early transmission dynamics in Wuhan, China, of novel coronavirus-infected pneumonia. N Engl J Med. 2020;382(13):1199-1207. doi: https://doi.org/ 10.1056/NEJMoa2001316

2. Yang Y, Peng F, Wang $R$, Guan $K$, Jiang $T, X u G$, et al. The deadly coronaviruses: The 2003 SARS pandemic and the 2020 novel coronavirus epidemic in China. J Autoimmun. 2020;109:102434. doi: https://doi.org/10.1016/j. jaut.2020.102434

3. Organização Panamericana da Saúde (BR) [Internet]. Brasília, DF: OPAS; c2020 [cited 2020 Apr 23]. Folha informativa - COVID-19; [about 1 screen]. Available from: https:/www.paho.org/

4. Ministério da Saúde (BR) [Internet]. Brasília, DF; c2020 [cited 2020 Jun 8]. Coronavírus Brasil - Painel Coronavirus; [about 1 screen]. Available from: https://covid.saude.gov.br/

5. Malik YS, Sircar S, Bhat S, Sharun K, Dhama K, Dadar M, et al. Emerging novel coronavirus (2019-nCoV): current scenario, evolutionary perspective based on genome analysis and recent developments. Vet Q. 2020; 40(1):68-76. doi: https://doi.org/10.1080/01652176.2020.1727993

6. Zarocostas J. How to fight an infodemic. Lancet (London, England). 2020;395(10225):676. doi: https://doi.org/10.1016/S0140-6736(20)30461-X

7. Moreira MF, Nóbrega MML, Silva MIT. Comunicação escrita: contribuição para a elaboração de material educativo em saúde. Rev Bras Enferm. 2003; 56(2):1848. doi: https://doi.org/10.1590/S0034-71672003000200015
8. Wiley D. Learning objects need instructional design theory. In: Rossett A, editor. ASTD e-Learning Handbook: best practices, strategies, and case studies for an emerging field. New York, NY: McGraw-Hill, c2002. p. 115-26.

9. nursingnowbr.org [Internet]. Brasília, DF: COFEN, C2019 [cited 2020Jun 8]. Available from: http://nursingnowbr.org/

10. Lima JS. Web Designear: bases conceituais e método de projetação para interfaces web [dissertação]. Feira de Santana (BA): Universidade Estadual de Feira de Santana; 2013 [cited 2020 Jun 8]. Available from: http://tede2.uefs. br:8080/handle/tede/90

11. Alves VLS, Cunha ICKO, Marin HF, Oliveira 0. Criação de um web site para enfermeiros sobre pé diabético. Acta Paul Enferm. 2006;19(1):56-61. doi: https://doi.org/10.1590/S0103-21002006000100009

12. Torres C. A bíblia do marketing digital. 1a edição. São Paulo: Novatec; 2009.

13. Aragão JMN, Gubert FA, Torres RAM, Silva ASR, Vieira NFC. The use of Facebook in health education: perceptions of adolescent students. Rev Bras Enferm. 2018;71(2):265-71. doi: https://doi.org/10.1590/0034-7167-2016-0604

14. Jin JM, Bai P, He W, Wu F, Liu XF, Han DM, et al. Gender differences in patients with COVID-19: focus on severity and mortality. Front Public Health. 2020;8:152. doi: https://doi.org/10.3389/fpubh.2020.00152

15. Centro Regional de Estudos para o Desenvolvimento da Sociedade da Informação (BR) [Internet]. São Paulo: Cetic.br; c2020 [cited 2020 Jun 9]. Três em cada quatro brasileiros já utilizam a Internet, aponta pesquisa TIC Domicílios 2019; [about 1 screen]. Available from: https://www.cetic.br/pt/noticia/tres-em-cada-quatrobrasileiros-ja-utilizam-a-internet-aponta-pesquisa-tic-domicilios-2019/ 
Motta LD, Freitas AA, Janovik Júnior RX, Blatt CR, Caregnato RCA

\section{- Authorship contribution:}

Conceptualization: Lindayane Debom Motta, Carine Raquel Blatt e Rita Catalina Aquino Caregnato.

Data curation: Lindayane Debom Motta.

Formal analysis: Lindayane Debom Motta, Carine

Raquel Blatt e Rita Catalina Aquino Caregnato.

Funding acquisition: Não se aplica.

Investigation: Lindayane Debom Motta, Aline Angeli de

Freitas e Ronei Xavier Janovik Júnior.

Methodology: Lindayane Debom Motta e Rita Catalina

Aquino Caregnato.

Project administration: Lindayane Debom Motta e Rita

Catalina Aquino Caregnato.

Resources: Lindayane Debom Motta, Aline Angeli de

Freitas e Ronei Xavier Janovik Júnior.

Software: Lindayane Debom Motta.

Supervision: Carine Raquel Blatt e Rita Catalina Aquino

Caregnato.

Validation: Lindayane Debom Motta, Aline Angeli de

Freitas, Ronei Xavier Janovik Júnior, Carine Raquel Blatt

e Rita Catalina Aquino Caregnato.

Visualization: Lindayane Debom Motta, Aline Angeli de

Freitas, Ronei Xavier Janovik Júnior, Carine Raquel Blatt

e Rita Catalina Aquino Caregnato.

Writing-original draft: Lindayane Debom Motta.

Writing-review \& editing: Lindayane Debom Motta, Carine Raquel Blatt e Rita Catalina Aquino Caregnato.

\section{- Corresponding author:}

Lindayane Debom Motta

Email: lindayane_d@hotmail.com

\section{Associate editor:}

Dagmar Elaine Kaiser

Editor-in-chief:

Approved: 12.03 .2020
Maria da Graça Oliveira Crossetti 